\title{
USING DATA MINING TO IDENTIFY FACTORS THAT INFLUENCE THE DEGREE OF LEG INJURIES IN BROILERS
}

\section{ALEXANDRA F. DA S. CORDEIRO ${ }^{1}$, MARTA DOS S. BARACHO ${ }^{2}$, IRENILZA DE A. NÄ̈̈S ${ }^{3}$, GUILHERME R. DO NASCIMENTO ${ }^{4}$}

\begin{abstract}
Locomotor problems prevent the bird to move freely, jeopardizing the welfare and productivity, besides generating injuries on the legs of chickens. The objective of this study was to evaluate the influence of age, use of vitamin $\mathrm{D}$, the asymmetry of limbs and gait score, the degree of leg injuries in broilers, using data mining. The analysis was performed on a data set obtained from a field experiment in which it was used two groups of birds with 30 birds each, a control group and one treated with vitamin D. It was evaluated the gait score, the asymmetry between the right and left toes, and the degree of leg injuries. The Weka ${ }^{\circledR}$ software was used in data mining. In particular, C4.5 algorithm (also known as J48 in Weka environment) was used for the generation of a decision tree. The results showed that age is the factor that most influences the degree of leg injuries and that the data from assessments of gait score were not reliable to estimate leg weakness in broilers.
\end{abstract}

KEYWORDS: decision tree, poultry, gait score.

\section{USO DE MINERAÇÃO DE DADOS PARA IDENTIFICAÇÃO DE FATORES QUE INFLUENCIAM O GRAU DE LESÕES DE PERNA EM FRANGOS DE CORTE}

RESUMO: Problemas locomotores impedem a ave de se movimentar livremente, prejudicando o bem-estar e a produtividade, além de gerarem lesões nas pernas dos frangos. O objetivo deste trabalho foi avaliar a influência da idade, do uso de vitamina $\mathrm{D}$, da assimetria de membros e do gait score, no grau de lesões de perna em frangos de corte, utilizando mineração de dados. A análise foi realizada em um conjunto de dados obtidos de um experimento de campo, em que foram utilizados dois grupos de aves com 30 aves cada, sendo um grupo-controle e outro tratado com vitamina D. Foram avaliados o gait score, a assimetria entre os dedos dos pés direito e esquerdo, e o grau de lesões de perna. O software Weka ${ }^{\circledR}$ foi utilizado na mineração de dados. Em particular, o algoritmo C4.5 (também conhecido como J48 no ambiente Weka) foi utilizado para a geração de uma árvore de decisão. Os resultados mostraram que a idade é o fator que mais influencia o grau de lesões de perna e que os dados provenientes das avaliações de gait score não se mostraram confiáveis para estimar problemas locomotores em frangos de corte.

PALAVRAS-CHAVE: árvore de decisão, avicultura, gait score.

\footnotetext{
${ }^{1}$ Zootecnista, Doutoranda em Engenharia Agrícola, FEAGRI-UNICAMP, Campinas - SP.

${ }^{2}$ Bióloga, Feagri-Unicamp, Campinas - SP.

${ }^{3}$ Eng $^{\mathrm{a}}$ Civil, Feagri-Unicamp, Campinas - SP.

${ }^{4}$ Doutorando em Zootecnia, UEM, Maringá - PR.

Recebido pelo Conselho Editorial em: 5-8-2011

Aprovado pelo Conselho Editorial em: 4-3-2012
} 


\section{INTRODUCTION}

Brazilian poultry farming is one of the most developed agricultural activities in recent decades. Brazil is now the world' third largest producer of broiler meat, allocating a significant portion of its production to the international market. Among the demands of the globalized market of poultry, there are countries that require the welfare of animals, and one of the important items of the concept of welfare is the absence of locomotor problems. Locomotor problems prevent the bird to move freely and, therefore, access equipment necessary for their survival, such as feeders and drinkers, undermining their well being and productivity (WEEKS et al., 2000; NÄÄS et al., 2009). Amongst the procedures for the mitigation of leg weakness in broilers, is the use of food supplement in the form of vitamin D (LEESON et al., 1995; MASSE et al., 2003).

The gait score is a measure of locomotor deficiency, in which is assigned a note related to the ability of the bird walking on a surface, for a certain period of time. Developed at the University of Bristol, England, this system has been used in the evaluation of leg weakness in broilers, whose methodology is the empirical observation of the movement of birds, using six levels of problems: 0 - no problem; 1 - moves fast, but shows little deficiency; 2 - moves fast, but presents deficiency, 3 moves fast, but has greater disabilities; 4 - moves with difficulty, and, 5 - hardly moves and drags with the wings (KESTIN et al., 1992). DAWKINS et al. (2004) proposed to simplify the rule, reducing it to three levels, based on the difficulty of diagnosing the intermediate levels, especially levels 2 and 3.

Problems difficult to solve as the detection of leg weakness in broilers could be better understood with the use of Data Mining, which is the extraction of new, understandable and useful knowledge from databases, and can be an interesting technique for recognizing patterns (REZENDE et al., 2003; HAN \& KAMBER, 2006). In recent years, it has been useful in many application areas (HOCHBERG et al., 2007; NAZERI et al., 2001; VALLE et al., 2008).

This study aimed to identify factors that influence the degree of leg injuries using the technique of data classification.

\section{MATERIAL AND METHODS}

\section{Field experimental data}

The experiment that generated the data used in data mining came from the rearing of $300 \mathrm{Cobb}^{\circledR}$ one-day old chicks, in six reduced model houses $(3.2 \times 1.4 \mathrm{~m})$, located in an open area at the Laboratory of Thermal Comfort and Environment, Faculdade de Engenharia Agrícola, UNICAMP. These sheds had east-west orientation, open at the sides and closed at the ends by walls. It was used polypropylene yellow curtains on the sides, which were closed when necessary, with the same management adopted commercially. It was used wood shaving bedding of $50 \mathrm{~mm}$ thick. In each house it was installed a commuting feeder and drinker. In the first two weeks, all birds received a starter diet for broiles (EM $3125 \mathrm{kcal} \mathrm{kg}^{-1}, 22 \%$ of NW), from 15 to 42 days a growing broilers diet (EM $3150 \mathrm{kcal} \mathrm{kg}^{-1}, 20 \%$ of NW), and a diet of finishing broilers (EM 3125 $\mathrm{kcal} \mathrm{kg}^{-1}, 20 \%$ of NW) was provided later. The birds were evenly distributed into two experimental groups, a control group and one with vitamin D added to the drinking water: Group 1 - control (without use of vitamin D): birds ingested a placebo $\left(0.2 \mathrm{~kg}\right.$ in $\left.1000 \mathrm{~L}^{-1}\right)$ added to drinking water and Group 2 - with vitamin D: birds ingested vitamin D in the form of 25-hydroxycholecalciferol $\left(0.2 \mathrm{~kg}\right.$ in $\left.1000 \mathrm{~L}^{-1}\right)$.

Thirty chickens were randomly taken of the building, at 42 and 49 days, to evaluate locomotor problems. The birds were weighed, identified and kept in a waiting room. The gait score was estimated for each bird using the scale $0-2(0=$ normal bird; $1=$ bird walks up to 10 steps with difficulty and has an imbalance between the legs; and 2 = bird that can barely walk or walks from 1 to 4 steps and sits down), as proposed by DAWKINS et al. (2004), by a person observing the bird walks. Then, the birds were sacrificed by cervical dislocation and rated the scores of tibial 
dyschondroplasia lesions, necrosis of the femoral head and Valgus and Varus deformities. It was also performed measurements of the tarsus and toes (toes 1,2, and 3) of right and left legs, with a digital caliper $(0.01 \mathrm{~mm})$, by two people (NUFFEL et al., 2007; POUCKE et al., 2007), to evaluate symmetry of members and toes. The study was approved by the Ethics Committee of Unicamp under number 1664-1/2009.

\section{Data analysis}

The experimental data were statistically analyzed and the result was considered statistically significant with P-value $\leq 0.05$.

To determine the influence of the injuries, it was carried out data mining, using program WEKA $^{\circledR} 3.5$ (WITTEN \& FRANK, 2005) and the algorithm J48 for cross validation of a sample of $10 \%$. The attributes used for classification have been described (Table 1), and the target attribute was the sum of the scores of injuries, which was obtained by summing the scores of tibial dyschondroplasia, necrosis of the femoral head and Valgus and Varus deformities). The database was composed of 96 comments.

TABLE 1. Attributes used in classification.

\begin{tabular}{ll}
\hline Attributes & Measures \\
\hline Vitamin D & Yes or No \\
Age & $4^{\text {th }}, 5^{\text {th }}, 6^{\text {th }}$ or $7^{\text {th }}$ week \\
Weight & $2,729.79 \mathrm{~g}^{*}$ \\
Backtoe & $16.02 \mathrm{~mm}^{*}$ \\
Outertoe & $20.51 \mathrm{~mm}^{*}$ \\
Miditoe & $20.64 \mathrm{~mm}^{*}$ \\
Tarsus & $59.11 \mathrm{~mm}^{*}$ \\
Gait score & 0,1 or 2 \\
Injury score sum (target attribute) & No injury, one to two, or three to four \\
\hline
\end{tabular}

*average of 30 birds used in experiment

\section{RESULTS AND DISCUSSION}

The results obtained with J48 algorithm using cross validation with samples of $10 \%$ and characterized by data processing are shown in Table 1. It is observed that the classifier had a poor performance, with only $52.08 \%$ accuracy in ratings, beyond the low value of Kappa statistics. These results may be due to the small number of observations (96) and variations of individual animals.

TABLE 2. Results obtained using the J48 algorithm and the cross validation process.

\begin{tabular}{lc}
\hline Weka ${ }^{\circledR}$ Processing Data & Cross validation \\
\hline Correct classifications & $52.08 \%$ \\
Incorrect classifications & $47.91 \%$ \\
Kappa Statistics & 0.22 \\
Mean absolute error & 0.28 \\
Error square root & 0.42 \\
Absolute relative error & 87.05 \\
Root Relative Squared Error & 105.29 \\
Total number of instances & 96 \\
\hline
\end{tabular}

Figure 1 shows the decision tree, obtained by processing the computer program WEKA ${ }^{\circledR}$ (3.5), using the C4.5 algorithm (better known as J48), for cross validation with samples of 10\% (10fold cross-validation). 


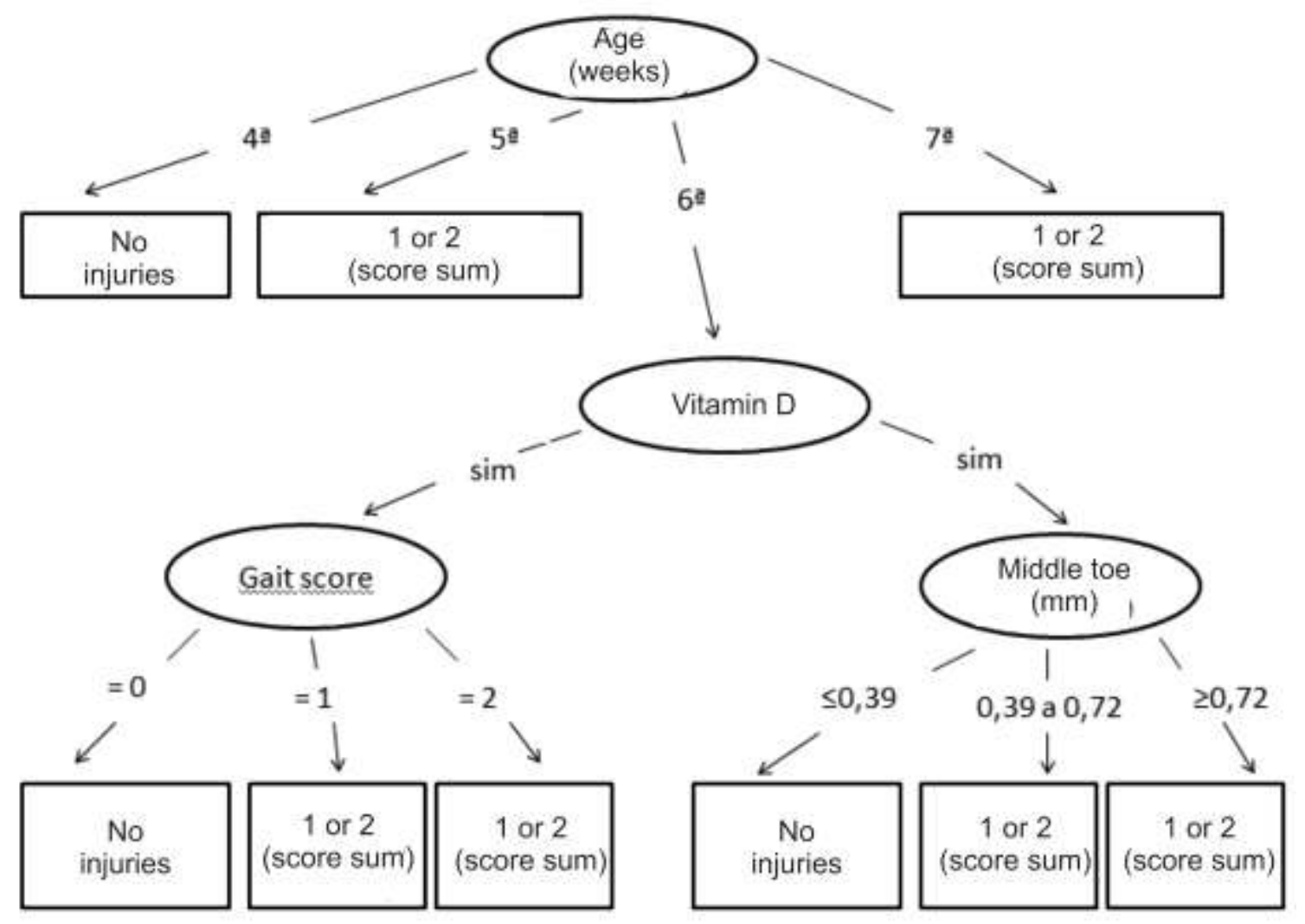

FIGURE 1. Decision tree using the algorithm J48.

Although the obtained classifier was not ideal, with a success rate of $52 \%$ of cases (with an accuracy of 0.547 for no injuries class and 0.556 for 1 or 2 score sum class) it was possible to identify some interesting results from processing the data. The most interesting rules obtained from decision tree (Table 3). According to the rules 1 and 5 the birds, in the fifth or seventh week had leg injuries. This result demonstrates the importance of further studies on the subject in order to minimize leg weakness in broilers. Rules 2, 3 and 4 show the influence of asymmetry score for leg injuries. For the birds that did not receive vitamin D, as it increase the difference of the toes 1 and 2 of the left and right legs, the score of legs injuries increased, however, the asymmetry has an attribute of minor importance in determining the amount of leg injuries. According POUCKE et al. (2007) the asymmetry did not influence the amount of leg injuries.

TABLE 3. Rules and respective descriptions extracted from the found decision tree.

\begin{tabular}{cl}
\hline Rule & \multicolumn{1}{c}{ Rule description } \\
\hline 1 & $\begin{array}{l}\text { If the bird is in the fifth week, then it has one or two injuries. } \\
\text { If the bird is in the sixth week and did not receive vitamin } \mathrm{D} \text {, and the difference } \\
\text { between outertoes was lower than } 0.39 \text {, then the bird does not have injuries. }\end{array}$ \\
$\begin{array}{l}\text { If the bird is in the sixth week and did not receive vitamin } \mathrm{D} \text {, and the difference } \\
\text { between toes was between } 0.39 \text { and } 0.72 \text {, then the bird has one or two injuries. }\end{array}$ \\
$\begin{array}{l}\text { If the bird is in the sixth week and did not receive vitamin } \mathrm{D} \text {, and the difference } \\
\text { between toes } 1 \text { and } 2 \text { was between } 0.39 \text { and } 0.72, \text { then the bird has three or four } \\
\text { injuries. } \\
\text { If the bird is in the seventh week, then the bird has one or two injuries. }\end{array}$ \\
\hline
\end{tabular}

Although the other rules showed lower novelty, they were interesting for validation of existing knowledge. According to the decision tree, at 28 days the chickens did not have leg 
injuries, and the degree of leg injuries rose from fifth to sixth week. According to SORENSEN et al. (2000), locomotion disorders are relatively less important at 28 days.

The benefits of vitamin D appeared in the sixth week of age, when it was observed that birds treated with vitamin $\mathrm{D}$ tended to have a lower degree of leg injuries. According to MASSE et al. (2003) vitamins D, A, C, K and B, as well as minerals as calcium and phosphorus and the relationship between them are essential to bone development. The deficiency or imbalance of vitamins and minerals are associated with rickets and tibial dyschondroplasia (LEESON et al., 1995). According to the authors, oxidized fat in the diet causes degradation of liposoluble vitamins including vitamins $\mathrm{D}, \mathrm{A}$, and $\mathrm{E}$, which can reduce the availability of these vitamins, resulting in locomotor problems.

It was also observed that the birds that had received vitamin D and had their estimated gait score 0 did not present leg problems, while those who received vitamin $\mathrm{D}$, but had gait score 1 or 2 , had the sum of the scores of injuries in 1 or 2 . SANOTRA et al. (2001) also reported a positive correlation between gait score and Valgus deformity, which affects the movement of broilers. An insufficient intake of vitamin D leads to an increased incidence of rickets and tibial dyschondroplasia (KLASING \& AUSTIC 2003). The tibial dyschondroplasia is one of the most common problems of the legs, being clinically detectable in animals older than 35 days old (CRESPO \& SHIVAPRASAD, 2003, OVIEDO-RONDÓN et al., 2009).

The way that the broilers move is not always affected by the incidence of some problems of internal injury, as femoral degeneration, or tibial dyschondroplasia and age, and there are cases in which the gait score can be the same for birds with or without these injuries. Perhaps the limited mobility of the chickens is more related to problems of joint deviations (FERNANDES et al., 2010). The same authors found a significant difference for articulation deviations between right and left legs and the different degrees of gait score with the largest deviation of articulation related to gait score 2 (a bird having walking trouble), indicating that this deformity can be related to gait score and age.

As for ESTEVEZ et al. (1997), the bird's locomotor activity decreases with age, while the time necessary for the rest is larger, increasing the incidence of injuries, probably as a reflection of the low quality of the bed and also the lack of exercise associated with weight gain may predispose to tibial dyschondroplasia. (KESTIN et al., 2001 and OVIEDO-RONDON et al., 2009). The origin of leg problems is not only related to bone problems, it should also be taken into consideration problems of tendons, joints, nerves, ligaments and muscular, and which are normally difficult to resolve (OVIEDO-RONDÓN et al., 2008).

From the tree obtained (Figure 1), it is possible to see that age was the attribute that most influenced the degree of leg injuries, while the gait score, which is a widely used method for estimating leg weakness, has less influence. CORDEIRO et al. (2009) also questioned the objectivity of gait score method. GARNER et al. (2002) and WEEKS et al. (2000) reported that the gait score, developed by KESTIN et al. (1992) is an empirical methodology and therefore relatively inaccurate. However, MEAGHER (2009) mentions that despite some challenges and limitations, this tool can be very useful and that is no less valid than any other estimate of capacity for locomotion of animals, since those measures are taken to avoid systematic biases in judgment, particularly if the data is obtained from multiple observers. Another important point mentioned by THOMPSON et al. (2008), is the importance of training the observers using this type of tool, and the lack of a detailed description of each score is a likely explanation for the inability to accurately detect locomotion diseases in broiler (FLOWER \& WEARY, 2006). This research used only one observer, but he was previously trained and probably this fact has not hindered the assessment of gait score.

OVIEDO-RONDÓN et al. (2008) mentioned that the evaluation of walking ability in broilers has been used as an indicator in audits of animal welfare, and, typically 1-2\% of all batches of broilers commercially housed present clinical signs of leg problems while other lots are affected in 
a subclinical way, which cannot be easily detectable. According to the decision tree obtained with the data from this study, individuals classified with gait score 0 in fact did not present leg injuries, although there was no difference in the degree of injury to individuals with gait score 1 or 2 . According to WEBSTER et al. (2008), fear or novelty can take the chicken to ignore the pain condition and walk or run normally, undermining the usual assessment of gait score, leading to rejections or partial housing and significantly increasing the cost per pound of body weight (OVIEDO-RONDÓN et al., 2008).

DANBURY et al. (2000) indicated that limping birds feel pain and, the more they limp, they feel more pain. Depending on the degree of limpness, the energy required for the locomotion can be increased, thus diverting part of the energy for their growth, leading to significant losses and a great heterogeneity in batches (WATERS \& MULROY, 1999).

The determining factor for the birds to move around depends on the genotype, nutrition and duration of food restriction (LEESON et al., 1995; MASSE et al., 2003; VAN DER EERDEN et al., 2003; BOKKERS \& KOENE, 2004; BOKKERS et al., 2007; BRUNO et al., 2007) and the mechanical and chemical properties of the bones (JAMROZ et al., 2004). However, this study observed only the factors related to the age of the birds, the dietary supplementation of vitamin D, injuries resulting from age and accommodation, and mechanics of locomotion determined by gait score.

\section{CONCLUSIONS}

The classifier developed through the decision tree indicates that age is the factor that most influences the degree of leg injuries, and the gait score method is not efficient for estimating locomotor problems in broilers. It is suggested that the use of a larger number of birds in the field experiment could result in a more accurate classifier.

\section{REFERENCES}

BOKKERS, E.A.M.; KOENE, P. Motivation and ability to walk for a food reward in fast and slowgrowing broilers to 12 weeks of age. Wageningen: Departament of Animal Sciences, Wageningen University, 2004.

BOKKERS, E.A.M.; ZIMMERMAN, P.H.; RODENBURG, T.B.; KOENE, P. Walking behaviour of heavy and light broilers in an operant runway test with varying durations of feed deprivation and feed access. Wageningen: Departament of Animal Sciences, Wageningen University, 2007

BRUNO, L.D.G.; LUQUETTI, B.C.; FURLAN, R.L.; MACARI, M. Influence of early qualitative feed restriction and environmental temperature on long bone development of broiler chickens. Journal of Thermal Biology, New York, v.32, p.349-354, 2007.

CORDEIRO, A.F.S.; NÄÄS, I.A.; SALGADO, D. Field evaluation of broiler gait score using Different Sampling Methods. Brazilian Journal of Poultry Science, Campinas, v.11, p.149-154, 2009.

CRESPO, R.; SHIVAPRASAD, H. Developmental, metabolic, and other noninfectious disorders" In: SAIF, Y.M. Diseases of poultry. $11^{\text {th }}$ ed. Ames: Iowa State Press, 2003. p.1055-1102.

DANBURY, T.C.; WEEKS, C.A.; CHAMBERS, J.P.; WATERMAN-PEARSON, A.E.; KESTIN, S.C. Self-selection of the analgesic drug carprofen by lame broiler chickens. Veterinary Record, London, v.146, n.11, p.307-311, 2000.

DAWKINS, M.S.; DONNELLY, C.A.; JONES, T.A. Chicken welfare is influenced more by housing conditions than by stocking density. Nature, Washington, v.427, n.1, p.342-344, 2004.

ESTEVEZ, I.; NEWBERRY, R.C.; ARIAS DE REYNA, L. Broiler chickens: A tolerant social system? Etologia, Barcelona, v.5, n.1, p.19-29,1997. 
FERNANDES, B.C.S.; MENDES, A.A.; MARTINS, M.R.F.B.; KOMIYAMA, C.M.; ALMEIDA PAZ, I.C.L.; MILBRADT, E.L.; SANFELICE, C.; FERREIRA, J.G.; NASCIMENTO, T.M. problems of legs in broiler chickens and its relationship with gait score. In: EUROPEAN POULTRY CONFERENCE, 12., Paris. Proceedings... Paris: WPSA. p.1-6, 2010. 1 CD-ROM.

FLOWER, F.C.; WEARY, D.M. Effect of hoof pathologies on subjective assessments of dairy cow gait. Journal of Dairy Science, Champaign, v.89, n.1, p.139-146, 2006.

GARNER, J.P; FALCONE, C.; WAKENELL, P.; MARTIN, M.; MENCH, J.A. Reliability and validity of a modified gait scoring system and its use in assessing tibial dyschondroplasia in broilers. British Poultry Science, Bristol, v.43, n.3, p.355-363, 2002.

HAN, J.; KAMBER, M. Data mining - concepts and techniques. 2.ed. New York: Morgan Kaufmann, 2006.

HOCHBERG, Y.V. Venture capital and corporate governance in the newly public firm. In: AFA American Finance Association Meetings, San Diego, 2004. Disponível em:

<http://ssrn.com/abstract=474542>. Acesso em: 10 jan. 2007.

JAMROZ, D. et al. Mechanical, chemical and spectroscopic analysis of mineralisation rate as methods of bones quality determination in broiler chickens. Electronic Journal of Polish Agricultural Universities, Cracóvia, v.7, n.2, [s/p], 2004. Disponível em:

<http://www.ejpau.media.pl/series/volume7/issue2/animal/art-04.html>. Acesso em: 15 nov. 2007.

KESTIN, S.C.; GORDON, S.; SU, G.; SORENSEN, P. Relationships in broiler chickens between lameness, liveweight, growth rate and age. Veterinary Record, London, v.148, n.7, p.195-197, 2001.

KESTIN, S.C.; KNOWLES, T.G.; TINCH, A.E.; GREGORY, N.G. Prevalence of leg weakness in broiler chickens and its relationship with genotype. Veterinary Record, London, v.131, n.2, p.190194, 1992.

KLASING, C.; AUSTIC, R.E. Nutritional diseases. In: SAIF, Y.M. Diseases of poultry. Ames: Iowa State Press, 2003. p.1027-1054.

LEESON, S.; DIAZ, G.; SUMMERS, J. Skeletal disorders. In: Poultry metabolic disorders and micotoxins. Guelph: Univ. Books, 1995. p.124-175.

MASSE,P.; BOSKEI, A.; ZIV, I.; HAUSCHKA, P.; DONOVAN, S.; HOWELL, D.; COLE, E. Chemical and biomechanical characterization of hyperhomoysteinemic bone disease in an animal model. 2003. Disponível em: <www.biomedcentral.com/1471-2474/4/2>. Acesso em: 15 jan. 2009.

MEAGHER, R.K. Review observer ratings: validity and value as a tool for animal welfare research. Applied Animal Behaviour Science, Amsterdam, v.119, n.1, p.1-14, 2009.

NÄÄS, I.A.; ALMEIDA, I.C.L.A.; BARACHO, M.S.; MENEZES, A.G.; BUENO, L.G.F.; ALMEIDA PAZ, I.C.L.; MOURA, D.J. Impact of lameness on broiler well-being. Journal of Applied Poultry Research, Ithaca, v.18, n.3, p.432-439, 2009.

NAZERI, Z.; BLOEDORN, E.; OSTWOALD, P. Experiences in mining aviation safety data. Santa Barbara: Association for Computing Machinery, Special Interest Group on Management of Data, 2001. p.21-24.

NUFFEL, A. VAN; TUYTTENS, F.A.M.; DONGEN, S. VAN; TALLOEN, W.E.; POUCKE, E. VAN; SONCK, B., LENS L. Fluctuating asymmetry in broiler chickens: A decision protocol for trait selection in seven measuring methods. Poultry Science, Ithaca, v.86, p.2555-2568, 2007.

OVIEDO-RONDÓN, E.O.; SMALL, J.; WINELAND, M.J.; CHRISTENSEN, V.L.; MOZDZIAK, P.S.; KOCI, M.D.; FUNDERBURK, S.V.L.; ORT, D.T.; MANN, K.M. Broiler embryo bone development is influenced by incubator temperature, oxygen concentration and eggshell conductance at the plateau stage in oxygen consumption. British Poultry Science, Edinburgh, v.49, n.3, p.666-676, 2008. 
OVIEDO-RONDÓN, E.O.; SMALL, J.; WINELAND, M.J.; CHRISTENSEN, V.L.; MOZDZIAK, P.S.; KOCI, M.D.; FUNDERBURK, S.V.L.; ORT, D.T.; MANN, K.M. Effects of incubator temperature and oxygen concentration during the plateau stage of oxygen consumption on turkey embryo long bone development. Poultry Science, Ithaca, v.87, n.8, p.1484-1492, 2008.

OVIEDO-RONDÓN, E.O.; WINELAND, M. J.; FUNDERBURK, S.; SMALL, J.; CUTCHIN, H.M.; MANN, M. Incubation conditions affect leg health in large, high-yield broilers. Journal of Applied Poultry Research, Ithaca, v.18, n.3, p.640-646, 2009.

POUCKE, E. VAN; NUFFEL, A. VAN; DONGEN, S. VAN; SONCK, B.; LENS, L.; TUYTTENS, F. A. M. Experimental stress does not increase fluctuating asymmetry of broiler chickens at slaughter age. Poultry Science, Ithaca, v.86, p.2110-2116, 2007.

REZENDE, S.O. Sistemas inteligentes: fundamentos e aplicações. São Paulo: Barueri, 2003.

SANOTRA, G.S.; LUND, J D.; ERSBOLL, A.K.; PETERSEN J.S.; VESTERGAARD, K.S. Monitoring leg problems in broilers: a survey of commercial broiler production in Denmark. World's Poultry Science Journal, Wageningen, v.57, n.2, p.55-69, 2001.

SORENSEN, P.; SU, G.; KESTIN, S.C. Effects of age and stocking density on leg weakness in broiler chickens. Poultry Science, Ithaca, v.79, n.6, p.864-870, 2000.

THOMPSON, P. T.; MUNKGAARD, L.; TOYERSON, F. A. Evaluation of lameness scoring in dairy cows. Journal of Dairy Science, Champaign, v.91, n.1, p.119-125, 2008.

VALE, M.M.; MOURA, D.J.; NÄÄS, I.A.; OLIVEIRA, S.R.M.; RODRIGUES, L.H.A. Data mining to estimate broiler mortality when exposed to heat wave. Scientia Agricola, Piracicaba, v.65, n.3, 2008.

VAN DER EERDEN, B.; KARPERIEN, B.M.; WIT, J. Systemic and local regulation of the growth plate. Endocrinology, Baltimore, v.24, n.3, p.782-801, 2003.

WATERS, R.L.; MULROY, S. The energy expenditure of normal and pathologic gait. Gait \& Posture, Downey, v.9, n.3, p.207-231, 1999.

WEBSTER, A.B.; FAIRCHILD, B.D.; CUMMINGS, T.S.; STAYER, P.A. Validation of a three. Point gait scoring system for field assessment de walking ability of commercial broilers. Journal of Applied Poultry Research, Ithaca, v.17, n.2, p.529-539, 2008.

WEEKS, C.A.; DANBURY, T.D.; DAVIES, H.C.; HUN, T.P.; KESTIN, S.C. The behavior of broiler chickens and its modification by lameness. Applied Animal Behaviour Science, Amsterdam, v.67, n.1-2, p.111-125, 2000.

WITTEN, I.H.; FRANK, E. Data mining: practical machine learning tools and techniques. $2^{\text {nd }}$ ed. San Francisco: Morgan Kaufmann, 2005. 525 p. 